\title{
The Personality of Environmental Prediction: Griffith Taylor as 'Latter-day Prophet'
}

\author{
Carolyn Strange
}

School of History, Research School of Social Sciences, Australian National University, Canberra, ACT 0200, Australia. Email: carolyn.strange@anu.edu.au

\begin{abstract}
Environmental prediction is a practice that may establish and enhance the status of predictors but it also carries risks that vary in relation to the professional and political contexts of its communication. Exploring the lives of scientists involved in the difficult task of environmental prediction highlights the significance of personal identities in the cultural history of science. Geographer Griffith Taylor (1880-1963), whose raison d'être was environmental prediction, is an ideal subject to examine from this perspective. Facing opposition to his early predictions of Australia's limited settlement prospects, owing to the continent's aridity, he used intemperate language to deliver sober warnings and sparred with naysayers and doubters in the popular media. By the 1920s he saw himself as a 'latter-day prophet', and he carried that sense of self forward when he moved to North America in 1928. Yet in Canada his environmental predictions, although favourable, were considered overly optimistic and often disregarded altogether. This prophet realized that he was happier being attacked than ignored. Taylor's career suggests that positive prognostication, when dismissed, offers less personal compensation than cautionary prophesies that face opposition in hostile political or intellectual contexts.
\end{abstract}

At the Third World Conference on Climate Change, in 2009, the Canadian meteorologist and television weather forecaster Claire Martin chaired a session on 'communicating climate information'. As the audience settled, she conducted a straw poll: 'who here believes that climate change is induced by humans? Who believes it results from naturally occurring phenomena? Who thinks they can say whatever they believe?' She noted a show of hands in response to her first two questions but none to the third. The results confirmed her belief that people engaged in environmental prediction, and those in the media reporting their findings, 'are frightened to say what they really think'. ${ }^{1}$ Martin's observation seems persuasive at a time when scientists are rallying to maintain consensus on global warming in the face of attacks from denialists and business interests, ${ }^{2}$ but the history of science is speckled with brave souls willing to challenge orthodoxy and defy convention, even at the risk of their careers. If Martin had conducted her poll ninety years earlier, when Griffith Taylor was launching his career as Australia's first academic geographer, her results might have been different. Had Taylor been in the room he would have raised his hand; more likely he would have waved.

According to leading scientific organizations, such as the United States National Center for Environmental Prediction (NCEP), 'the environmental forecast process' is a disembodied craft that requires: 'observations; analysis; model; forecast; post-processed model data; forecaster; user'. In this formula, which emphasizes the recent reliance on statistical modelling, raw material goes in (oceanographic, climatographic and solar data) and predictions of likely consequences (droughts, sea-level changes, ice-cap melting, soil salinity and their effects on human, animal and plant life) come out, with the forecaster a disinterested processor. ${ }^{3}$ Environmental prediction is not always so bloodless, however, and 
nor is it always communicated by anonymous bureaucrats. The telegenic faces and well-crafted sound bites of gifted science communicators, invited on to national news programmes to discuss the likely impact of climate change, indicate that personality and historical moment shape the formulation, articulation and reception of environmental prediction. ${ }^{4}$ The genres and media used to communicate predictions have transformed over the past century, as have the political contexts and economic implications of scientists' predictions. Examining the careers of individuals attracted to this sometimes precarious and often politically charged sub-field of predictive science during the past century provides an intriguing line of inquiry into the cultural history of science. ${ }^{5}$

With the rise of the sociology of scientific knowledge and constructivism, scholarship moved away from the history of 'great minds' toward the social, cultural and political dimensions of knowledge production. The growing appreciation of science as a cluster of practices to be analysed, rather than a dispassionate set of ideas and methods to be evaluated for their merits, has turned attention to practitioners. Historical biographies informed by a constructivist approach have focused on the 'social collectivities' in which scientists work and the ways in which scientists have implicated themselves in adapting to and helping to shape disciplines, institutions, national research agendas and public debates. ${ }^{6}$ As individuals adapt, they engage in 'selffashioning' although, as sociologists Daston and Sibum stress, the character-building work that goes into the formation of scientific 'personae' occurs in families, homes and friendship networks, and not just in laboratories or the field. ${ }^{7}$

While biographical studies enjoy a resurgence throughout the discipline of history, ${ }^{8}$ taking a biographical approach to subjects whose pursuits resonate with currentday political and scientific preoccupations offers a unique way to historicize interventions that would otherwise appear to be novel research agendas. Numerous Australian scientists involved in current debates about the prospects of sustainable development for the country's future have acknowledged Griffith Taylor (1880-1963) as a forebear. Geographer Ruth Fincher noted that Taylor had paid a great price in the 1920 s by rejecting plans for Australia that were based on political hubris and business greed rather than on sound environmental planning: 'some fairly unhappy things happened to Griffith Taylor'. ${ }^{9}$ His unpleasant experience and flight from Australia to North America in 1928 convinced subsequent geographers that, notwithstanding their expertise, it was unwise to become ensnared in national debates. Tim Flannery takes a more sanguine view of Taylor's legacy. He considers him 'one of the greatest and most courageous scientists Australia has ever produced', precisely because he dared 'to tell the truth about the future of the nation'. ${ }^{10}$ Taylor, like Flannery, was a scientifically trained public communicator who exploited the media of his day - scholarly and popular science books, articles and research reports, illuminated lectures, travel writing and editorials - to reach a diverse audience with a message many cared not to hear. But the times were different and so was Taylor's reception (no 'Australian of the Year' for him). Thus the risks of cautious projection were greater in the early-twentieth century, and it took an obdurate character to hold his tune rather than to sing with a chorus chanting 'Australia Unlimited'.

While Taylor's infamous 'battle with the boosters' has become something of a trope in the historiography of nationalism in postFederation Australia, this dramatic cameo appearance in the nation's history was only his most notable role in a much longer career on the international stage of environmental prediction. ${ }^{11}$ Wherever he travelled, taught or talked he was ready to risk 
his reputation and that of the discipline he helped establish by proclaiming longrange environmental forecasts relevant to settlement and economic prospects. In his 1928 presidential address to the New South Wales Geographical Society, which he co-founded, Taylor declared, 'if the mantle of the prophet has fallen on anyone it is on the shoulders of the geographer, though usually the politician has claimed it as his own! ${ }^{12}$ A full appreciation of Taylor as an environmental predictor requires considering the Canadian half of his career however. Between 1935 and 1951 he worked in a political and economic milieu distinct from that of Australia in the 1920s, and Canada's Taylor was a man in later life, who lived in the country at time when security concerns took precedence over settlement plans, and who had moved to a natural environment with features that justified more positive predictions for the future. ${ }^{13}$ In the unfamiliar role of optimist he failed to create a stir, however, let alone controversy. Still, the ambition and sense of purpose that led to his collision with the Australian nationalist agenda never faltered. In old age he came to realize that he was happier being opposed than overlooked.

\section{Self-appointed Prophet}

No historical figure is better suited than Griffith Taylor to illustrate the role that personality may play in the communication of and responses to environmental forecasts. ${ }^{14}$ A scientist who bridged the divide between the academy and the citizenry, he published his assessments with prestigious university presses and in highly regarded journals, including the proceedings of the Pan-Pacific Science Congress and the Australasian Association for the Advancement of Science; simultaneously he sent opinion pieces to daily newspapers, submitted articles to mass-circulation magazines, and delivered hundreds of illustrated talks, often spiked with caustic commentary about his opponents, whom he called 'false patriots'. Why? What drives a scientist to pitch his environmental predictions for popular audiences, especially when the message they bear is unpopular? ${ }^{15}$ Taylor often wondered the same thing, as he complained to a colleague in 1925: 'It is not all beer and skittles being a minor (or minimus) latter-day Prophet!'16

Taylor's self-description referred to the hostile reception he had received in response to his forthright warnings about Australia's limited capacity for agricultural development and population growth. Yet he refused to back down and he never lost confidence in the authority of his pronouncements. Taylor was an agnostic but he trafficked in the common coin of biblical language and allegory. ${ }^{17}$ As he warned his Anglican-raised fiancée, 'I must see some why or wherefore or analogy to something I know to be true before I can ascertain a theory'. ${ }^{18}$ His professional credentials upheld his high opinion of his authority to speak as a man of science. From 1920 he headed Australia's first academic geography department, based at the University of Sydney. Prior to that, the Commonwealth Bureau of Meteorology (BoM) had employed him throughout the 1910s, including the war years. His research as the Bureau's 'physiographer' informed the planning of the new national capital in the Molonglo valley that became Canberra, and he provided environmental assessments in response to the Australian Government's plans to settle and develop 'White Australia'. From his first official appointment to his final days, environmental prediction was more than a job: it was Taylor's raison d'être.

Modern scientists accrue status by embodying the model of the working self proclaimed by the NCEP: research is rigorously reviewed and communicated objectively through government and academic publications. Taylor's one-time chief, Henry A. Hunt, was made for this model. The BoM's first director, he was a prize-winning 
scholar recognized for his work on the storm system known on Australia's east coast as the 'Southerly Buster'. He travelled the world to acquaint himself with meteorological research in other countries before settling down at the Bureau in 1907. He became a faithful civil servant committed to building up his department's stature by hiring Taylor, a university-trained expert. The professionalization of meteorology hinged on its practitioners' credentials, a signal preoccupation of modern science's denigration of 'popular' sources of knowledge such as farmers' almanacs, folk practices such as water divining, and the environmental wisdom of Indigenous peoples. ${ }^{19}$ As far as Hunt was concerned, if theories and the projections derived from them could not be proved or ascertained with mathematical precision, they ought not to feature in scientific reports. Yet at the same time, government ministers demanded that the BoM answer pressing questions: could the nation's 'empty spaces' support an expanded pastoral industry? Could the tropical north be settled and defended by white settlers? Everyone had opinions but, Hunt insisted, only trained scientists had the expertise to answer such questions. Outsiders and amateurs like Inigo Jones, a largely self-taught meteorologist who issued seasonal weather projections based on supposed cyclical variations in solar activity, were dismissed by the BoM. A hierarchy of knowledge and status was constructed and defended through Hunt's refusal to take Jones seriously until pressured to do so by rural pastoralists and their representatives in Parliament in the late 1930s.

The story of this 'weather prophet' is one we might expect: earnest outsider versus institutionally located scientists who stayed within the lines of established and testable mathematical models of forecasting and policed the boundary. It is not Taylor's story however. ${ }^{20}$ Predictive science for Taylor was the practical fulfilment of his intellectual commitment to environmental determinism: 'Man' might imagine that he was a free agent, able to shape his future, he observed, but 'Nature's plan' had always shaped and would always shape the future of human endeavour. ${ }^{21}$ In an article titled, 'New Lands and Old Education' he spelled out his enduring concern: 'I fear that politics are controlled rather by expediency than by scientific knowledge, although so many of our problems turn on the complete understanding of the Australian environment. ${ }^{, 22}$ This conviction grew from Taylor's tutelage in the long intellectual tradition of natural history, which took the whole of life - the oceans, the continents, plants, animals and humanity - within its scope, at a temporal scale that connected deep time to the present distribution of resources and humans. If environment, climate and humans had been interlinked since the dawn of time, the expert with knowledge of that history could predict the future. By the early twentieth century most geographers turned to closer regional studies as units of analysis. When it came to the relation of 'Man' to 'Nature', the orientation of modern geography, as espoused by such leading figures as Carl Sauer, emphasized human ingenuity and its capacity to overcome the limitations of the physical environment. ${ }^{23}$ Taylor recognized that his views were heretical but he was sufficiently confident to defend them against disciplinary orthodoxy. For example, he used his 1942 presidential address to the American Association of Geographers to attack possibilism, 'not because [the possibilist] seems often to be mainly on the lookout to see where man has exercised his powers over Nature, but because he rather tends to ignore the vastly greater importance of environmental control in most parts of the world'. ${ }^{24}$ His opponents were not just wrong but misguided: 'It is absurd to say that man can choose which he pleases among many possible directions ... We must learn the path clearly indicated by Nature'. ${ }^{25}$ Thus it was not only outsiders 
who understood themselves as persecuted prophets, but an opinionated insider as well. Despite the resistance, his conviction never wavered: 'it is the geographer's duty to interpret this programme'. 6

Taylor's own travels reinforced his belief in environmental determinism. David Livingstone's observation that 'particular spaces matter in the production, consumption and circulation of science' and to the scientist's identity is an insight that Taylor expressed in more prosaic ways. ${ }^{27}$ In 1938, speaking as president of the Geography Section of the British Association for the Advancement of Science, he proudly declared that the environments within which his intellect had developed had determined his determinism, 'owing to my experience in pioneer countries like Australia and Canada, where the possibilities offered by Nature to Man are more meagre than in Britain or the U.S.A.' ${ }^{28}$ Taylor's tenacity cannot be explained solely, however, through the shifting environments of his career, and nor can his own interpretations of his character development (and a man who wrote two autobiographies offered many) substitute for an analysis of this scientist's approach to environmental prediction.

\section{Self-fashioning}

Recent biographical scholarship has moved beyond chronicling the life and times of 'super-heroes' to consider how subjectivities, formed amidst professional and family relations as well as institutional settings, social circles and cultural matrices, shape all forms of scientific knowledge. ${ }^{29}$ When the styles in which scientists communicate knowledge and the audiences to which they address their ideas become objects of inquiry, a biographical approach is called for, especially in the case of practitioners whose communicative acts violated professional custom. Through their passions and ambitions, their elation and disappointment, individuals such as Taylor substantiate the claim that personal identities and life histories are central to the cultural history of science. ${ }^{30}$

Taylor was no Galileo, yet he always believed that he had been cast in the same mould of daring truth-teller, beset by doubters and detractors. More than a scientist with a purpose, he was a man of purpose who interpreted disapprobation as ignorance. Speaking before the Australasian Association for the Advancement of Science in 1923 he described his decade-long attempt to convince statesmen, fellow academics and the public of Australia's limited settlement prospects as 'one long period of disillusionment'. ${ }^{31}$ Nevertheless Taylor's mentors, his associates and colleagues, his students and his closely knit family recognized that he was stubborn by nature and immune to self-doubt. What made him a closed-minded scholar made him an enthusiastic leader of junior scholars and teacher of teachers, in Australia, the USA and especially Canada. Leading and following defined his make-up. As an old man, casting his eyes over a case-full of medals and a wall papered with awards from learned societies, he paid homage to the debts he owed to his father, who catapulted from desperate poverty to professional appointments as an international mining consultant, and to his life-long mentor, the Sydney-based geologist T. W. Edgeworth David, regarding both with filial respect. ${ }^{32}$ To advance his career beyond Australia, he courted senior academics in the USA, Britain and Europe. In every other aspect of his career, however, he set his own course, often ignoring advice that he should approach his work with greater tact. ${ }^{33}$

When Taylor began his university studies in 1899, the discipline of geography had yet to take root in Australia, and his own training took in a wide range of subjects. ${ }^{34}$ His scientific studies began under Edgeworth David at the University of Sydney, where he earned undergraduate degrees in geology, 
physics and mining engineering. Taylor's father had become a scientist by working his way into the London School of Mines and the son climbed several rungs higher by winning a prestigious 1851 Exhibition science research scholarship that took him to Cambridge in 1907, where he was recognized as one of the British Empire's most promising young scientists. He graduated in 1909 with a BA (research) degree, roughly the equivalent of a $\mathrm{PhD}$ before Cambridge began to offer them, for his paleontological project on Archaeocyathanae. ${ }^{35}$ When his father and David combined forces to concoct a position for him back in Australia in the Bureau of Meteorology, Taylor was just about to leave for Antarctica, where he served from 1910 to 1912 with the British Antarctic Expedition as Chief Geologist. As a compromise he performed double duty for the weather service and for Captain Scott, returning to Australia at the age of 31 with proven experience in field work and an impressive breadth of expertise in meteorology, glaciology and geology.

A fertile mix of academic attainment, family ties and mentoring relationships allowed Taylor's native ambition to flower. Alongside his official duties, as the BoM's physiographer, to assess soil, temperature and precipitation data, he began in the late 1910 s to forecast on a grand spatial scale, projecting forward and peering backward in time. This mode of thinking owed a great deal to Edgeworth David, who taught geology by linking earth science to 'the Antiquity of Man'. ${ }^{36}$ Above all David outlined the public-minded scientist's mission- to convey his expertise concerning the earth and its past to nation planners, to the public, and to future generations. David could see that Taylor, more than any of his other gifted students, was the one who took that mission to heart. When the professor convinced the University of Sydney's administrators in 1919 that it ought to establish a geography department, and that his former pupil ought to head it, the offer came at the right time. Life as a functionary within a bureaucracy was not in Taylor's blood: climate, not weather, was the subject that gripped his mind. Hunt resented the restless physiographer's self-promotion and his hunger for the limelight, while Taylor yearned to set his own research agenda. Besides, he could now finally catch up with his peers such as Douglas Mawson and Thomas Laby, who had secured academic posts long before him.

Taylor eagerly followed in his professor's path but he was leaden-footed, where David knew to tread lightly and to speak with a gentle tongue. His brusque delivery of the nation-planning credo won him more critics than followers, as became painfully clear during the course of the 1920s. As Joseph Powell observes, Taylor was oblivious to the "complicated personal and societal setting wherein all forms of theoretical and empirical research are initiated, organized and communicated'. ${ }^{37}$ Facing exponents of an abrasive nationalism, everyone from bush patriots to prime ministers, Taylor fought back with facts about Nature's limited bounty toward the Australian continent. He poured scorn (and heaps of climate, soil and vegetation data) on the officially endorsed yet ludicrous schemes then promoted to settle Australia's arid zones, with a projected national population that would match or even exceed that of the USA. Taylor predicted that the country's population would reach no more than nineteen million by the century's end, since its vast areas of poor soil and meagre and unreliable rainfall could not be willed away. ${ }^{38}$ There was nothing radically new in Taylor's declarations. In the mid-nineteenth century, William Stanley Jevons concluded that irregular rain had always been and would continue to be a characteristic feature of Australia's climate, while the South Australian Surveyor-General, George Goyder, had mapped districts that were unsuitable for agricultural development as determined by the reliability of rainfall. ${ }^{39}$ What was new was the timing and delivery of 
the message, and the personality of the messenger.

In the 1920s, Taylor addressed national ambitions far out of proportion to the continent's environmental capacities. With a characteristic touch of perversity, he pointed effectively to earlier patterns of environmentally determined settlement elsewhere in the world that showed clearly that 'folk of European stock' were best suited to the 'homoclimes' of temperate zones, not the energy-draining tropics and deserts that made up much of Australia. ${ }^{40}$ If 'White Australia' were to succeed, it would do so only along the fertile and well-watered strips where European settlers had already exploited environments favourable to agriculture and closer settlement. Australia had been dreamed up out of political and racial ambition but the expert geographer could see that the continent, not the national map, would determine its future. ${ }^{41}$ Predictions of this nature were bound to be unpopular but in Taylor's case they provoked censure in Parliament and derision in the press, where he took up cudgels against anyone who questioned his authority. ${ }^{42}$ After Harold Nelson, an MP from the Northern Territory, set out to prove him wrong about the aridity of inner Australia, Taylor could barely contain his delight when the politician failed: 'He was found nearly dead of thirst by a search party which rescued him just in time. This proves little, of course, but it seemed to me not unlike poetic justice! ${ }^{43}$

Relief from the public battles of his Sydney career came in 1928, when the University of Chicago offered him a professorship. At the University of Sydney's farewell reception, his fellow academics could afford to be gracious with the campus gadfly. Still, they felt compelled to point out the personal qualities that had made him stand his ground. The Vice-Chancellor spoke of Taylor's 'downrightness, his absolute honesty of purpose, his devotion to his subject, and if he might so express it, his fine indiscretions'. An insecure soul might have squirmed at the suggestion that his professional behaviour was something below the professional standards expected of an academic and the holder of the university's hard-won geography chair. But Taylor returned home that night to write and tell several of his friends about the 'indiscretions' remark, and he retold it in his autobiography ('In replying I could not but remark that I felt myself in danger of committing just one or two more before leaving!'). Taylor was forever composing his self-portrait as the scientist indiscreet by design, not by accident. ${ }^{44}$ If ever he felt the need for inspiration he could always reach for Edgeworth David's farewell exhortation: 'bring more light to dark places'. ${ }^{45}$

Colourful, publicity-seeking personalities inevitably stand out against modern science's deliberately sober, even tedious face and the 'dull and frigid and calm' characters drawn to it. ${ }^{46}$ Taylor, having been brought up in a household of eccentric nonconformists, was constitutionally averse to conforming to type. From his earliest years he was a contradictory character, hungrily accumulating credentials while behaving like a 'buccaneer'. ${ }^{47}$ His spiteful remarks were spiked with wit (patriots could call the Central Desert 'the Garden of Eden, but it would still be as dry'), ${ }^{48}$ and his sophomoric sense of humour leavened his spirits whenever he felt himself under attack. Feeling alone against the world and plagued by boils, he could have folded his tent by the early 1920s. Instead, he wrote. In one of his rare fictional works, 'An Egyptian Allegory', he invented the story of 'TwoTank', a Pharaoh who is seduced by 'Polly-Titian'. This lady is so concerned about the declining treasury that she urges her King to develop the Sahara 'beyond the Palm Trees ... yellow as gold and thrice as valuable'. The lone naysayer is a 'tailor' and 'MINOR PROPHET', who pleads before TwoTank:

I have travelled through your kingdom, and I have consulted all the Archives. Do not do this thing! For I say that ye shall not 
find sustenance for the camel's fleas-let alone for the camel-in the centre of your kingdom. Multiply your crops in the fertile margin. So shall ye prosper.

Tragically the King ignores these wise words. TwoTank dies, but he reawakens forty centuries later, only to see the Saharan sands 'as golden as ever ... and as empty'. ${ }^{49}$

\section{Bearer of Good Tidings}

Taylor carried the persona of the persecuted prophet with him when he crossed the Pacific to North America, but the audiences for his predictions were different as were the environments in which he lived and taught. Although he worked at the University of Chicago in the early years of the Depression, he was surprisingly reticent as the American Midwest transformed from bread-basket into dust bowl. He certainly had not lost his hunger for publicity, as his efforts to capitalize on Robert Byrd's Antarctic explorations and his popular writings on science and exploration confirm. ${ }^{50}$ If his Australian experience dulled his appetite for public prediction, his move to Canada in 1935 whetted it.

Linking Taylor's little-known work in Canadian long-range forecasting to the familiar story of his Australian period highlights the differences between cautionary environmental prediction and optimistic environmental projection. ${ }^{51}$ Both negative and positive outlooks invite scrutiny when they are broadcasted widely but favourable ones become controversial only when they prompt poor investments or lead to environmental catastrophes. Yet they must be noticed. Taylor continued to hold his torch of enlightenment as he confronted a new challenge: how to deliver a positive message?

When Taylor took up an invitation from the University of Toronto to establish Canada's first university-based geography department, he felt himself on familiar ground-the premier geographer in a country beset by considerable climatic challenges but blessed with enormous territory. ${ }^{52}$ The time seemed right for an expert to appear and to assess its settlement prospects. Or so he anticipated. At the age of fifty-five Taylor arrived at the University of Toronto with a twenty-year track record in predicting future settlement possibilities. In recognition of the work he had conducted in Australia, the President of the American Geographical Society, Isaiah Bowman, had invited Taylor in 1927 to contribute to a major project on 'the main pioneer regions' of the world. Bowman's undertaking, funded by the United States National Research Council and the Social Science Research Council, enlisted researchers to examine undeveloped agricultural lands 'in the two temperate and the two sub-tropical belts, specifically in Canada, Brazil, Rhodesia, Siberia, Manchuria-Mongolia, and Australia'. As one of a panel of international experts, Taylor wrote the chapter on Australia and contributed to the project's overall goal to marshal expertise in order to develop 'wise administrative policy', both nationally and internationally. ${ }^{53}$

In view of this background, Taylor imagined that he would continue his prediction work in relation to settlement from his new base at the University of Toronto. He set to work immediately, publishing articles and books on his adopted country's environment and its prospects for economic development and population expansion. As he stooped over his typewriter, glancing out his office window to watch the snow blanket leafless maple trees, he transplanted his expertise on a hot, dry environment to a cool one: 'Each continent has its own controls of future settlement. For instance, in Canada, to which the writer has now transferred his main attention, temperature is the major control and rainfall takes no more than second rank'. ${ }^{54}$ In 'Future Population in Canada: a study in technique', the country was new but the method was tried and true: 'if parallel developments in regions of similar climate, but further advanced, are studied ... it is not 
difficult to show what the next few stages of development will be'. 55

Taylor taught the correlative mode of reasoning and instructed his followers to do the same: 'I find it well to remind my students that the geographer carries out such research in four stages; the Plan, the Pattern, the Principles and then the Prophecy! 56 A well-trained geographer could prophesy the future by plotting data on soil, vegetation, rainfall and temperature on isopleth maps; using this method Taylor calculated the Canadian environment's carrying capacity at 100 million people, five times greater than Australia's. As he recycled his earlier publications on Australia during the 1940s and 1950s, the contrast between Canadian possibilities and Australian limits became ever clearer in his mind: 'So strongly have I felt the need for some plan to direct statesmen in their efforts to build up a strong nation', he wrote in 1951, it was his duty to convey his wisdom concerning Canada's development potential. ${ }^{57}$ And so Taylor lectured. He trained student teachers. He published textbooks distributed to hundreds of thousands of baby-boomer school children. He delivered popular lectures. He wrote newspaper articles and editorials extolling Canada's development potential. He wrote for glossy magazines.

Canada's forecast was rosy, he urged, because its environmental resources ensured a prosperous and more powerful future. In a piece of popular prognostication that he titled 'Canada in 100 Years' (published in Chatelaine, the country's leading women's magazine), he predicted that the nation's coal resources would determine the principal zone of its population expansion. The East's coal resources would be exhausted by the mid-twenty-first century, but Alberta's beckoned investment. In particular he thought the Mackenzie-SlavePeace river basin had enormous natural resources that could be harnessed. The environmentally determined development that historical economist Harold Adams Innis had charted for eastern Canada-based initially on 'fish and fur', then 'forestry, farming and factories'-would not hold in the future development of the prairies, foothills and valleys of the West. ${ }^{58}$ And the natural limits of forests, arable land and frigid temperatures in these regions would never support the dense population base of southern Ontario and Quebec. Fortunately, much of northern Canada could support the cultivation of cold-weather crops, in contrast to Australia's 'empty land', which he continued to consider 'useless', ${ }^{59}$ In the 1920s, when Taylor's warnings about Australia's environmental limits had provoked hostility, Bowman had given him sensible advice: 'Make a constructive effort instead of destroying the pretty and false pictures which others paint'. ${ }^{60}$ Two decades later, Taylor was finally accentuating the positive, not because he had changed his creed but fittingly, because he had become a creature of different climate and environment.

Global politics played a role as well in Taylor's transition to good news agent. Although he spoke out forthrightly against European fascism, he never took a stance against communism. ${ }^{61}$ In the interwar period his own home became a site for debates between Taylor, a classic liberal, and his elder son, Bill, who joined the Cambridge Socialist Club and travelled to the Soviet Union in the mid-1930s. 'I wish he wasn't so obsessed by Bolshevism', Taylor confided to his mother. ${ }^{62}$ Yet he found communism's modernist cast appealing and he appreciated the Soviet approach to settlement projections. Studying the Soviet Union's 'scientific colonization based on scientific planning' was one of his primary research projects at Toronto, where he taught the geography of Canada's sub-Arctic comparatively. ${ }^{63}$ He had always argued that 'the key to progress will be planning in accord with the environment', but now he added 'as we have seen in Soviet Russia'. ${ }^{64}$ In a 1946 publication, 'Parallels in Soviet and Canadian Settlement', 
he hailed the success of the Soviets as well as the Finns in their development of regions similar in topography and climate to Canada's Mackenzie Valley. ${ }^{65}$ In the mid-1940s he prepared a series of lectures on the Soviet Union in which he argued that there was no reason why regions of Canada, that shared Siberian temperature, rain and soil 'isopleths' could not likewise plant cold-weather crops beyond the wheat belt. Viewing the Soviet experience from his comfortable Toronto post, he thought the free world had a lot to learn when it came to appreciating geography's unique contribution to expert nation planning:

Geographers do not claim to be infallible.

We aim to look farther ahead than financial and economic forecasters who make shorttime predictions. We can only make fairly accurate forecasts from what has happened in other parts of the world. ${ }^{66}$

No gulag awaited Taylor if his 'fairly accurate predictions' turned out to be inaccurate; working in a democratic country, his challenge was to convince the Canadian public and politicians that geographical knowledge was crucial for environmentally suitable development. He understood that the 'realization of the prophesies I outline here ${ }^{67}$ was a matter of persuasion, so he poured his energy into the training of geography teachers and he rarely turned down an opportunity to publish. To fulfil his mission his message had to reach all Canadians, from school children and home-makers to Cabinet Ministers.

What more could the man do? Even though Taylor speculated that an expanded population base would elevate Canada's geopolitical status, politicians and government departments showed little inclination to listen to the aging geographer. ${ }^{68}$ He was not wholly ignored in Canada, however, since he continued to publish in Canadian and international academic journals. His fellow academics were polite but their reviews of his Canadian work criticized any prediction based on the 'homoclime' method. More significantly, Taylor's Canadian forecast had a patchy empirical base, far less solid than the data he had amassed through his Bureau of Meteorology work and his extensive field research in Australia. He leapt to conclusions based on superficial impressions of the Canadian environment, gathered, literally, on whistle-stop tours and driving trips with his son, Bill, holding the wheel while he scratched away on his note pad. In Taylor's mind this was what made him a 'scientific observer', superior to the ordinary traveller who 'make[s] few deductions of value to science' ${ }^{69}$ At the end of a breakneck, three-week train trip across western Canada in 1936, Taylor wrote home confidently to his wife, Doris: 'I doubt if anyone in Canada knows the details of this route much better than I do, so I'm no longer a new-chum geographer here'. ${ }^{70}$ Doris may have taken him at his word but his fellow geographers were harder to convince. Members of the University of British Columbia's Department of Geography and Geology who reviewed Taylor's Canadian manuscripts for publishers filled page after page with notes of errors and recommendations that he improve his knowledge of Canadian geomorphology before pronouncing on it. ${ }^{71}$

Even a fellow outsider could spot the logical leaps in Taylor's work on Canada's environmentally determined settlement prospects. English-born geographer George H. T. Kimble, whom McGill University hired in 1944 to establish the country's second department of geography, was conscious that Taylor had recommended him. Mindful of his debt, he gave Taylor's Canada: A Study of Cool Continental Environments a gracious but critical review. He paid his respect to 'the man whom many of us have come to regard as the doyen of British geographers - and the most omniscient of them', then he launched his attack. Credible environmental prediction 
required careful scrutiny of physical data, not 'the analogue method of reasoning'. Strangely Taylor seemed to have turned into the sort of wide-eyed booster he had attacked twenty years earlier in Australia. As a specialist in medieval geography, Kimble conceded that crops could be grown beyond the wheat belt but he doubted that 'a diet of mangolds, turnips, and potatoes won from a reluctant soil frost-bound all the year (and so ill-drained), low in humus and organic compounds, would ever constitute much of an attraction to intending settlers'. Surely Canadians of the twenty-first century would likely expect and demand better. In essence Kimble doubted that future living standards could be projected solely on the basis of the natural environment, a point Fincher echoed in $2004 .^{72}$

As a teacher of future academics and geographers with nation-planning expertise, Taylor fared far better. One of his graduates, William C. Wonders, built up the department of geography at the University of Alberta where he became an expert in Arctic cartography and settlement, a field of research that assumed great importance in Cold-War Canada. ${ }^{73}$ Female former students fared well under Taylor's direction, with Marie Sanderson the most successful. A hydroclimatologist, she began her career at the University of Windsor, where she was a professor of geography and the founding director of the Great Lakes Institute for Environmental Research in the 1980s, when pollution and acid rain were devastating aquatic systems. Sanderson began writing on the water-climate balance in the Great Lakes in the mid-1960s and by the 1980s was a recognized world authority on climate and water management. ${ }^{74}$ These and numerous other former students maintained respect and deep affection for Taylor, even though none of his followers went on to carry his standard of environment determinism. ${ }^{75}$

Retirement in 1951 and his departure from Canada did not spell the end of
Taylor's career. On the contrary it led to its sunniest days. When he returned to Australia he encountered a new generation of geographers and scientists who focused on his earlier environmental predictions rather than his recent Canadian research, and cast the senior geographer in a respectful light. Oskar Spate, one of the Australian National University's earliest social scientists and a friend of Taylor's in his later years, called him the 'prodigal father' of Australian geography. ${ }^{76}$ The warm reception disarmed him. His nomination as a fellow of the Australian Academy of Science in 1954 made him the first geographer to receive the honour, and the institution he had fled, the University of Sydney, bestowed an honorary doctorate on him in 1957. Praise poured in from former students such as Ann Marshall, who wrote a tribute to him in 1961 on the occasion of his eightieth birthday: 'Time has shown the accuracy of his opinions, and the same newspapers which once criticized him severely now state "he probably ranks as one of the greatest geographers in the world today"', ${ }^{77}$ Acclamation as the first president of the Institute of Australian Geographers came in the same year, another mark of respect for the doughty disciplinary founder whose sacrifices had helped pave the way for geography to gain academic credibility. These accolades allowed Taylor to maintain his great trick of self-deception: his opponents were ignorant, irrational or misguided, while he was the clear-headed scientist on a professional mission to pursue and publicize knowledge. The satisfaction he felt at his welcome home to Australia was profound. In letter after letter sent to former students and colleagues who had remained loyal to him, even when their opinions differed, he retold the story of the prophet's vindication.

\section{Conclusion}

Considering environmental prediction through the life of a scientist suggests that this sub-field of predictive science draws 
personalities willing to take professional risks. When they were high, as they were for Taylor in the 1920s, he put his own reputation on the line, but even when they were lower, as they were in the 1930s and 1940s in Canada, he gambled with the status of the discipline he helped to found and that of the prestigious academic institutions and learned societies that had hired and nominated him to prestigious posts. For those with position, breaking the conventions of science communication has more to do with personality than with data. Taylor rarely waited for invitations from the media for commentary; rather, he manipulated every medium at his disposal, for better or worse. The current crop of environmental podcasters and YouTube producers attempting to shape their own messages in order to dodge the journalistic practice of 'the balancing norm' is catching up with Taylor. ${ }^{78}$

Despite the scientific and secular cast of environmental prediction, it falls within the rubric of prophecy, a core construct of moral education in the Judaeo-Christian tradition. The prophet's role is not so much to foretell the future as to warn his people of the misfortune they court if they pursue their unwise ways. Floods, fires, famines, plagues and droughts are among the disasters that befall those who fail to heed the prophet's word. ${ }^{79}$ Taylor's adoption of a secularized religious persona underscored the authority of his environmental predictions and anchored him in a stormy sea of disbelief. Ironically his prophetic inclinations were least fulfilled when the message he delivered was positive. Five years into his tenure at the University of Toronto he mused to Bowman, 'Isn't it interesting that after 20 years of vilification for trying to control ignorant boosters in Australia that I am now thought too optimistic'. ${ }^{80}$ While his Canadian studies were poorly researched compared to the standards he had maintained earlier in his career, Taylor's career is not simply the tale of one scientist's declining standards. What it suggests, rather, is that positive prognostication, if dismissed, offers little personal compensation compared to cautionary prophecies that are ignored or attacked in hostile political or intellectual contexts. The scientists willing to step into the fray are those who savour vindication as the sweetest reward, even knowing that it may not come in their lifetimes. Taylor, an academic who believed firmly that modern science involves the detached, disinterested pursuit of truth, was living proof of the constructivist understanding of science as a practice fuelled by emotion and ambition as much as intellect. ${ }^{81}$ How might Taylor react if he knew that his predictions would receive favourable reviews a century after he first publicized them? How might he respond to the news that a scientist who had been named Australian of the Year had celebrated his courageous adherence to the truth? As much as he sought endorsement and craved accolades, Taylor never required others to sustain his belief that 'Man, like every other living creature, is a parasite on the surface of the earth, depending entirely on the distribution of the gifts of Mother Nature'. ${ }^{82}$

\section{References}

1. http://www.wcc3.org/sessions.php? session list=R-3, accessed 20 March 2010.

2. In Australia a 'Climate Sceptics Party' (the 'world's first') was established in 2009 by Leon Ashby, an 'Australian landholder [who ... .] lost property rights due to the Kyoto protocol and other environmental laws'. The party aims to promote 'scepticism and objectivity in climate policy'. See http://climatesceptics.com.au/, accessed 25 March 2010. See also Ian Plimer, Climate Change: Global Warming the Missing Science (London, 2009).

3. Stephen J. Lord, 'Overview of the Environmental Modeling Centre: The Environmental Forecast Process' (Camp Springs, MD: National Center for Environmental Prediction, [n.d.]), $\mathrm{http}: / /$ www.emc.ncep.noaa.gov/EMC2006A. pdf, p. 9. As the director explains: 'Virtually all the meteorological data collected over the globe arrives at NCEP, where environmental scientists analyse this information 
and generate a wide variety of environmental guidance information'. http://www.ncep. noaa.gov/director/ (both accessed 16 March 2010).

4. Two excellent studies that emphasize the personalities and personal networks of science are Vladimir Jankovic, Reading the Skies: A Cultural History of English Weather, 1650 1820 (Chicago, 2001) and Richard Holmes, The Age of Wonder: How the Romantic Generation Discovered the Beauty and Terror of Science (London, 2008).

5. Many of the same observations might be made of theoretical physics, for example, in which scientific theories generate reasoned claims about future events, which are falsifiable, reproducible, consistent, and reliant on existing data.

6. Jan Golinski, Making Natural Knowledge: Constructivism and the History of Science. Second Edition (Chicago, 2005), p. 9.

7. Lorraine Daston and H. Otto Sibum, 'Introduction: Scientific Personae and their Histories', Science in Context, 16(1-2) (2003), 1-8. This issue featured biographical approaches to the cultural analysis of science's history.

8. In 2009 the American Historical Review devoted a roundtable to the resurgence of biography as practised by leading historians. In 2006 Isis devoted a special issue on science and biography. For the biographical approach's relationship to social history see Nick Salvatore, 'Biography and Social History: an Intimate Relationship', Labour History, 87 (November 2004), 187-192.

9. Ruth Fincher, 'Geography and the PopulationEnvironment Debate', in Proceedings of the 2004 Fenner Conference on the Environment, Australian Academy of Science, para. 5, http://www.science.org.au/events/fenner/fenner2004/fincher.htm, accessed 14 December 2009.

10. Timothy Fridtjof Flannery, The Future Eaters: An Ecological History of the Australian Lands and People (Sydney, 2005), pp. 363-364.

11. Taylor's now-standard place in Australian national historiography is reviewed in the introduction to Carolyn Strange and Alison Bashford, Griffith Taylor: Visionary, Environmentalist, Explorer (Toronto, 2009).

12. Griffith Taylor, 'The Status of the Australian States. A Study of Fundamental Geographical Controls, The Australian Geographer, 1(1) (1928), 7-28, p. 8.

13. When Taylor arrived in Canada the threat of 'undesirables' (Communists, criminals, and the poor) and the Depression's economic and social impact dominated the political agenda. Carolyn Strange and Tina Loo, Making Good: Law and Moral Regulation in Canada, 18671939 (Toronto, 1996).

14. This theme was explored in a multidisciplinary event, 'Violent Ends: the Arts of Environmental Anxiety', held at the National Museum of Australia on 9 June 2009. See http://www. nma.gov.au/violent_ends/, accessed 2 December 2009.

15. The cost is often isolation and marginalization, as Rachel Carson discovered. See Mark Hamilton Lytle, The Gentle Subversive: Rachel Carson, Silent Spring, and the Rise of the Environmental Movement (New York, 2007).

16. Taylor to Huntington, 27 May 1925, Box 41, Folder 1109, Ellsworth Huntington Papers, Yale University Library.

17. U.S. labour leader Eugene Debs, like Taylor, betrayed similar characteristics in his socialist rhetoric. See Nick Salvatore, Eugene V. Debs: Citizen and Socialist (Urbana, 1982).

18. Taylor to Doris Priestley, 26 February 1914, quoted in Strange and Bashford, Griffith Taylor, p. 115 (emphasis in original).

19. Euro-Australian acknowledgement of Aboriginal people's knowledge of country, in light of colonial mismanagement of the Australian environment, is belatedly underway. See Jessica Weir, Murray River Country: An Ecological Dialogue with Traditional Owners (Canberra, 2009).

20. Tim Sherratt, Inigo Jones: The Weather Prophet, METARCH Papers 16 (Melbourne, 2007).

21. Griffith Taylor, Environment and Race: A Study of Evolution, Migration, Settlement and Status of the Races of Man (London, 1927).

22. Griffith Taylor, 'New Lands and Old Education', Pacific Affairs, 2(2) (1929), 54-57, p. 55 .

23. George Tatham, 'Environmentalism and Possibilism', in Geography in the Twentieth Century: a Study of Growth, Fields, Techniques, Aims, and Trends, ed. Griffith Taylor (Toronto, 1951), 128-162; Joseph M. Powell, 'Taylor, Stefansson and the Arid Centre: An Historic Encounter of "Environmentalism" and "Possibilism", Journal of the Royal Australian Historical Society, 66(3) (1980), 163-183.

24. Griffith Taylor, 'Environment, Village and City: A Genetic Approach to Urban Geography, with Some Reference to Possibilism', Annals of the Association of American Geographers, 32(1) (1942), 1-67, p. 2.

25. Griffith Taylor, Geography in the Twentieth Century, p. 12. For the development of 
Taylor's anti-possibilist stance in the 1920s see Joseph M. Powell, 'The pulse of citizenship: reflections on Griffith Taylor and "nation-planning", Australian Geographer, 28(1) (1997), 39-52.

26. Griffith Taylor, Australia, A Study of Warm Environments and Their Effect on British Settlement (London, 1941), p. 445.

27. David Livingstone, 'Text, talk and testimony: geographical reflections on scientific habits. An afterword', British Journal of the History of Science, 38(1) (2005), 93-100, pp. 92, 100.

28. Griffith Taylor, 'Correlations and Culture: a study in technique', Scottish Geographical Magazine, 54 (November 1938), 321-344, p. 339.

29. Jan Golinski, 'The Theory of Practice and the Practice of Theory: Sociological Approaches in the History of Science', Isis, 81 (1990), 492-505; Mary Jo Nye, 'Scientific Biography: History of Science by Another Means?', Isis, 97 (2006), 322-329.

30. On the value of biography beyond the pantheon of scientific 'superheroes' see Elizabeth Baigent and Felix Driver, 'Biography and the history of geography: a response to Ron Johnston', Progress in Human Geography, 31(1) (2007), 101-106, and Trevor Barnes, 'Lives lived and lives told: biographies of geography's quantitative revolution', Environment and Planning D: Society and Space, 19(4) (2001), 409-429, and Michael Shortland and Richard Yeo, 'Introduction', in Telling Lives in Science: Essays on Scientific Biography, eds Michael Shortland and Richard Yeo (Cambridge, 1996), 1-46, p. 37. Despite the growing sophistication of scholarly literature on science biography the approach remains on the defensive. See Thomas Söderqvist, " "No Genre of History Fell Under More Odium than that of Biography": The Delicate Relations between Scientific Biography and the Historiography of Science', in The History and Poetics of Scientific Biography, ed. Thomas Söderqvist (London, 2007), 241-262.

31. Griffith Taylor, 'Geography and Australian National Problems', Report of the Australasian Association for the Advancement of Science, 16 (1924), 433-487, p. 453.

32. Griffith Taylor, Journeyman Taylor: the Education of a Scientist (London, 1958). While many scientists, such as Einstein, wrote autobiographies that revealed little below their brains or beyond their thoughts, some did. See in particular the chapter on 'intellectual passions' in Michael Polanyi's, Personal Knowledge:
Towards a Post-Critical Philosophy (London, 1958), 132-202.

33. This interpretation of Taylor's personality is developed in greater depth in Strange and Bashford, Griffith Taylor, chapter four.

34. Libby Robin and Tom Griffiths, 'Environmental History in Australasia', Environment and History, 10(4) (2004), 439-474. For geography's intellectual heritage prior to its appearance in the academy see David N. Livingstone, The Geographical Tradition: Episodes in the History of a Contested Enterprise (Oxford, 1992); Derek Gregory, Ideology, Science and Human Geography (London, 1978).

35. Griffith Taylor, 'The Archaeocyathinae from the Cambrian "Coral Reefs" of South Australia, with an Account of the Morphology and Affinities of the Whole Class', Memoirs of the Royal Society of South Australia, 2 (1910), 55-188.

36. On Edgeworth David as a scientist and mentor see David Branagan, T.W. Edgeworth David: A Life. Geologist, Adventurer, Soldier and 'Knight in the Old Brown Hat' (Canberra, 2005).

37. Joseph M. Powell, Griffith Taylor and 'Australia Unlimited' (St. Lucia, 1993), p. 181.

38. Griffith Taylor, 'Australia as a Field of Settlement', Foreign Affairs, 5(4) (1927), 679-681, p. 681. His estimates varied over the earlytwentieth century but circulated around the twenty-million mark.

39. Neville Nicholls, 'William Stanley Jevons and the Climate of Australia', Australian Meteorology Magazine, 47 (December 1998), 285-293; Janis Sheldrick, 'Goyder's Line: the unreliable history of the line of reliable rainfall', in A Change in the Weather: Climate and Culture in Australia, eds Tim Sherratt, Tom Griffiths and Libby Robin (Canberra, 2004), $56-65$

40. For example see Griffith Taylor, 'Geography and Australian National Problems', and Griffith Taylor, 'The Geographer's Aid in NationPlanning', The Scottish Geographical Magazine, 48(1) (1932), 1-20.

41. Libby Robin, How a Continent Created a Nation (Kensington, 2007).

42. Powell, 'The pulse of citizenship'.

43. Griffith Taylor, 'The Inner Arid Limits of Economic Settlement in Australia', The Scottish Geographical Magazine, 48(2) (1932), 65-78, p. 65. Taylor recounted this story in numerous subsequent publications.

44. Taylor, Journeyman Taylor, pp. 205-206.

45. David to Taylor, 28 October 1928. MS1003, Box 8, Papers of Thomas Griffith Taylor, 
National Library of Australia (hereafter Taylor collection).

46. Shortland and Yeo, 'Introduction', p. 9.

47. Taylor, Journeyman, p. 17.

48. Griffith Taylor, 'Australian National Problems', Report of the Australasian Association for the Advancement of Science, 16 (1924), 433-487, p. 466. This remark rings with Nicholas Stern's witty dismissal of global warming deniers: 'You may not like the laws of gravity, but that doesn't mean you can levitate'. ABC Lateline, 1 December 2009, http://www.abc.net.au/lateline/content/2008/ s2759127.htm, accessed 11 December 2009.

49. This story, hand-written in June 1921, was never published. Taylor collection, Box 47.

50. Carolyn Strange, 'Griffith Taylor's Antarctica: Science, Sentiment and Politics', Polar Record, 46(1) (2010), 65-74.

51. Carolyn Strange, 'Transgressive Transnationalism: Griffith Taylor and Global Thinking', Australian Historical Studies, 41(1) (2010), 25-40.

52. Harold Adams Innis was a political economist and historian at the University of Toronto who became interested in Taylor's environmental determinist work. The attraction waned after Taylor moved to Toronto and Innis's work moved toward theories of communication. Alexander John Watson, Marginal Man: The Dark Vision of Harold Innis (Toronto, 2006).

53. W.L.G. Joerg to Taylor, 7 June 1927. Taylor collection, Box 18, item 889.

54. Griffith Taylor, 'The Possibilities of Settlement in Australia', Limits of Land Settlement, ed. Isaiah Bowman (New York, 1937), 195-227, p. 195.

55. Griffith Taylor, 'Future Population in Canada: a study in technique', Economic Geography, 22(1) (1946), 67-74, p. 67. Taylor used his considerable visual skills to demonstrate this technique in his signature graphics. See David R. Oldroyd, 'Griffith Taylor and His Views on Race, Environment, and Settlement, and the Peopling of Australia', in Useful and Curious: Geological Enquiries Beyond the World - Pacific-Asia Historical Themes: the 19th International INHIGEO Symposium, eds D.F. Branagan and G.H. McNally (Sydney, 1994), 251-274.

56. Taylor, 'Future Population', p. 67.

57. Griffith Taylor, 'Geopolitics and Geopacifics', in Geography in the Twentieth Century, 587-608, p. 597.

58. Though Innis' senior, Taylor had great respect for his work, particularly the staples thesis Innis developed in The Fur Trade in
Canada: An Introduction to Canadian Economic History (Toronto, 1930).

59. Griffith Taylor, 'Canada 100 years from now', Chatelaine Magazine (February 1945), 14-15, 46-47. In 1944 he published a similar article, directed to 'girl geographers', in Mademoiselle Magazine. Thomas Fisher Rare Book Library, MS 20 Box 22(13) (hereafter Fisher).

60. Bowman to Taylor, 24 September 1924. Taylor collection, Box 18, item 767. See also Joseph M. Powell, 'The Bowman, Huntington and Taylor Correspondence, 1928', Australian Geographer, 14(2) (1978), 123-125.

61. Taylor believed that the war had been justified but took no public or private stance against Stalinist politics. However he did publicly support NATO and the United Nations: 'As long as we have thieves we must have police; and as long as Fascist and extreme national ideas persist, we need strong forces of an international type to check them'. Taylor, Our Evolving Civilization, p. 607.

62. Taylor to 'Mater', 11 December 1935, Taylor Collection, Box 20.

63. Griffith Taylor, Our Evolving Civilization: an Introduction to Geopacifics (Toronto: University of Toronto Press, 1946), p. 346.

64. Griffith Taylor, "Dynograph” of World Industry', Vital Speeches of the Day, 10(5) (1943), 144-147, p. 144.

65. Griffith Taylor, 'Parallels in Soviet and Canadian Settlement', International Journal, 1(2) (1946), 144-158.

66. Taylor, Our Evolving Civilization, p. 47.

67. Taylor, 'Canada 100 Years from now', p. 47.

68. Griffith Taylor, 'Canada's Role in Geopolitics, A Study in Situation and Status', Canadian Institute of International Affairs, Contemporary Affairs Series No. 16 (Toronto, 1942), p. 27.

69. Taylor, Our Evolving Civilization, p. ix.

70. Taylor to Doris Taylor, 20 July 1936, Taylor Collection, Box 20, item 1732.

71. Fisher C, Box 12 (02).

72. G.H.T. Kimble, Review: Canada: A Study of Cool Continental Environments (London, 1947), in Geographical Review, 11(1/3) (1948), 108-111. Kimble's reference to 'omniscience' chimes with Donna Haraway's concept of modern science's 'god-trick' of seemingly seeing everything from nowhere. William Grassie, 'Donna Haraway's metatheory of science and religion: cyborgs, trickster, and Hermes', Zygon Journal of Religion and Science, 31(2) (2005), 285-304.

73. Wonders edited an authoritative pioneering collection, Canada's Changing North 
(Toronto, 1971), which was revised and republished in 2003.

74. Sanderson credits Taylor as an early inspiration in her biography, Griffith Taylor: Antarctic Scientist and Pioneer Geographer (Ottawa, 1988).

75. Among his Canadian students were Donald Innis, Harold Innis' son, who taught at Queen's University; H.D. Watts of the University of Manitoba; Lloyd Reed of McMaster University, and Rosemary Graham of the Conservation Council of Ontario. For a fuller study of Taylor as a teacher see Strange and Bashford, Griffith Taylor, chapter four.

76. Oskar Spate to Taylor 13 Aug 1951, Box 10, Series 5, Folder 5/1/2, Papers of O.H.K. Spate, National Library of Australia.

77. Ann Marshall sent Taylor a copy of her reflections on his career, published in the Proceedings of the Royal Geographical Society of South Australia. She also published an affectionate but balanced obituary after his death in 1963: Ann Marshall, 'Griffith Taylor', Geographical Review, 54(3) (July 1964), 427-442.
78. Climate scientist, Will Steffen criticized this journalistic practice in his address at the Australian Academy of Science, 'Climate Change 2010: Where do we go from here?', 10 March 2010, http://www.youtube. com/watch? $\mathrm{v}=8 \mathrm{wX} 1 \mathrm{rLqRfNc}$, accessed 23 March 2010.

79. Kate Rigby, 'Ecological Consciousness and Local Action: Prophetic Voices of the Limestone Plains', paper delivered at 'Violent Ends', 9 June 2009: http://www.nma.gov. $\mathrm{au} / \mathrm{research} / \mathrm{centre}$ for_historical_research/ conferences_and_seminars/violent_ends $2 /$ ecological_consciousness/, accessed 2 December 2009 .

80. Taylor to Bowman, 19 June 1940, Taylor Collection, Box 20.

81. Kirsten Hastrup provides an excellent example of environmental history fully integrated with human history in 'Destinies and Decisions: Taking the Life-World Seriously in Environmental History', in Nature's End: History and the Environment, eds Sverker Sörlin and Paul Warde (London, 2009), 331-349.

82. Taylor, Our Evolving Civilization, p. 361. 